\title{
LUGONES Y LA GUERRA: ÉPICA Y VIOLENCIA
}

\begin{abstract}
A vosotros no os aconsejo el trabajo sino la lucha. A vosotros no os aconsejo la paz sino la victoria. ¡Sea vuestro trabajo una lucha, sea vuestra paz una victoria! Friedrich Nietzsche, Asi habló Zaratustra
\end{abstract}

\section{PRIMERAS ARMAS}

Poeta modernista, padre fundador de la literatura nacional argentina, ideólogo del primer fascismo criollo, si hay una marca que identifique a ese escritor múltiple y contradictorio que fue Leopoldo Lugones esta es, sin duda alguna, la violencia. Batirse a duelo en las quintas de Belgrano, cargar en el bolsillo del pantalón una Smith \& Wetson del 38, practicar esgrima en el Círculo Militar, tiro de pistola en el Tiro Federal, escribir, no fueron en Lugones sino variables de una misma práctica y un mismo proyecto: guerra y violencia. Más allá de valoraciones estéticas y diferencias ideológicas, la violencia y la guerra que la supone constituye el denominador común de los múltiples retratos lugonianos que nos ha legado la crítica. A poco de conocer a Lugones, Rubén Darío nos presenta al poeta como un "fanático", un "convencido inconquistable" de "espíritu vibrante y violento"1; Alfonso Reyes nos habla del "atletis-

1 "Un poeta socialista: Leopoldo Lugones", El Tiempo, 12 de mayo de 1896, p. 5. Citamos la obra de Leopoldo Lugones por las siguientes ediciones: Primeras letras de Leopoldo Lugones, guía prelim. y notas L. Lugones, hijo, Centurión, Buenos Aires, 1963; Las montañas del oro, pról. R. Darío, Editorial Rioplatense, Montevideo, 1919; Lunario sentimental, ed. J. Benítez, Cátedra, Madrid, 1988; La guerra gaucha, pról. y notas L. Lugones, hijo, Centurión, Buenos Aires, 1962; Las fuerzas extrañas, A. Moen y Hermano, Buenos 
mo característico de su fuerte personalidad"2; Octavio Amadeo, un poco más sobrio, apunta su "espíritu de capitán y conquistador"3; Ezequiel Martínez Estrada hace de Lugones un "soldado civil"4. Masiva, abrupta, salvaje y brutal, primer síntoma del exceso que lo recorre, la violencia constituye una realidad omnipresente en el universo lugoniano. Reiterados y por momentos cargantes, sus textos no dejan de narrar la historia de una guerra. Su escritura pone en escena, una y otra vez, las alternativas de un combate. Los títulos de sus libros lo anuncian una y otra vez: La guerra gaucha, Mi beligerancia; su "beligerancia" habría que decir: la guerra lugoniana.

Misión del artista, programa y consigna del escritor, la guerra define la escena fundadora y el punto de partida del itinerario del poeta. En julio de 1897, apenas llegado a Buenos Aires, Lugones habla en El Ateneo. En un texto que puede leerse como un manifiesto de vanguardia, o lo que es lo mismo, como una declaración de guerra, Lugones presenta el programa de la nueva generación literaria. Dice allí el joven poeta:

Nuestra misión es de lucha, de lucha dolorosa y probablemente harto larga. El deber de soldados es intransferible... Jóvenes soldados del arte, vosotros que habéis decidido entrar en guerra por el ideal... levantad bien alto las banderas y enviad al sol vuestro saludo... iJóvenes soldados del Grande Ejército: presentad las armas! (Primeras letras, p. 67).

Aires, 1906; Las limaduras de Hephaestos. Piedras liminares, A. Moen y Hermano, Buenos Aires, 1910; Las limaduras de Hephaestos. Prometeo (un proscripto del sol), Otero, Buenos Aires, 1910; Historia de Sarmiento, Comisión Argentina de Fomento Interamericano, Buenos Aires, 1945; El ejército de la Ilíada, Otero, Buenos Aires, 1915; El elogio de Ameghino, Otero, Buenos Aires, 1915; El payador, pról. J. L. Borges, sel., notas y cronología G. Ara, Ayacucho, Caracas, 1979; Mi beligerancia, Otero y García, Buenos Aires, 1917; El tamaño del espacio, El Ateneo, Buenos Aires, 1921; La torre de Casandra, Atlántida, Buenos Aires, 1919; Acción. Las cuatro conferencias del Coliseo, Círculo Tradición Argentina, Buenos Aires, 1923; Estudios helénicos, Babel, Buenos Aires, 1924; Nuevos estudios helénicos, Babel, Buenos Aires, 1928; La patria fuerte, Círculo Militar, Buenos Aires, 1930; La grande Argentina, pról. L. Lugones, hijo, Huemul, Buenos Aires, 1962; Roca, pról. O. Amadeo, Comisión Nacional Monumento al Teniente General Julio A. Roca, Buenos Aires, 1938.

2 "Leopoldo Lugones", Nosotros, 1938, núms. 26/28, p. 334.

3 "Prólogo" a Leopoldo Lugones, Roca, p. 20.

${ }^{4}$ Leopoldo Lugones, retrato sin retocar, Emecé, Buenos Aires, 1964, p. 65. 
Las armas y las letras se conjugan en la escritura lugoniana. Soldado del arte, Lugones dicta en 1905 una conferencia cuyo título - El ejército de la Ilíada- y el auditorio - el Círculo Militar de Buenos Aires-, son más que sugerentes. Dice entonces el poeta al grupo de oficiales del ejército que escucha su disertación: "vengo a invocar entre vosotros y yo la familiaridad del acero. Mi profesión también es armada" (p. 14).

Garantía de hombría, certificado de dignidad, secreto y pulso de la vida, la guerra es para Lugones no sólo la condición y el destino del artista, sino también de todo hombre que se precie como tal. En junio de 1913, en ocasión de sus famosas conferencias sobre el Martín Fierro, Lugones se dirige al público del Teatro Odeón. "El secreto profundo de nuestra vida", apunta allí el poeta, "la «milicia» de los teólogos, la «lucha» de los sabios, consiste en que ella es un eterno combate por la libertad. Sin esto no existiría la dignidad de la condición humana. Por ello los hombres no pueden vivir sino peleando de esta manera" (El payador, p. 24).

En octubre de 1917, con motivo de la ruptura de relaciones diplomáticas entre Uruguay y las potencias centrales, Lugones arenga a la multitud convocada ante el Palacio de Congresos de Montevideo. Guerrero infatigable, Lugones hace evidente allí una beligerancia, la suya, que trasciende la coyuntura bélica europea. Dice allí el poeta:

Todas estas cosas, ciudadanos, no han hecho sino empezar. Detrás de la guerra actual contra los déspotas, hay otra guerra dentro de casa y dentro de uno mismo. Es ésa la guerra futura que será menester sostener para eliminar hasta la entraña misma todo lo que reste de iniquidad y de infamia (La torre de Casandra, p. 146).

Poeta civil, pero no por ello soldado sin ejército, atento a las necesidades logísticas de su guerra, y en un gesto que prefigura al escritor japonés Yukio Mishima, Lugones arma en 1923 su propio ejército privado ${ }^{5}$. En el acto fundante de la Guardia Nacional Voluntaria, el poeta-soldado se dirige al auditorio na-

5 Aludo a la "Sociedad del escudo", Tatenokai, organización paramilitar de defensa de los valores nacionales fundada por Yukio Mishima como milicia privada en 1968. Sobre el militarismo en Mishima, figura tan lejana culturalmente al universo lugoniano, pero tan próxima al escritor argentino en lo que hace a una sensibilidad guerrera, véase el excelente ensayo de Marguerite Yourcenar, Mishima ou la vision du vide, Gallimard, Paris, 1980. 
cionalista que llena la platea del teatro Coliseo en los siguientes términos: "Qué vale la vida si no es vivida por el hombre en la lucha que la hermosea, como en la alarma de su soledad magnífica se le encrespa y dora la melena al león" (Acción, p. 63). Lugones hace explícito el carácter de la "Agrupación patriótica" de "soldados de la nación" que allí se funda. El "programa de acción" de la Guardia Nacional, apunta el poeta, "reconoce la violencia como un medio ante los obstáculos que lo exijan" (p. 77).

Más que de "hora de la espada", habría que hablar en Lugones de vida de y por la espada. Su arenga de Ayacucho de 1924, su famoso discurso de "la hora de la espada", apunta la necesidad del combate como un elemento constitutivo a toda vida que se pretenda completa: "La vida completa", dice, "se define por cuatro verbos de acción: amar, combatir, mandar, enseñar. Pero observad que los tres primeros son otras tantas expresiones de conquista y de fuerza. La vida misma es un estado de fuerza" (La patria fuerte, p. 18). Tres años más tarde, septiembre de 1927, Lugones confirma sus postulados desde las páginas de La Nación:

Podemos afirmar que el género humano es una entidad zoológica... feroz como los carnívoros. La guerra constituye para él una función vital, resultante de su índole conquistadora y agresiva. Único entre las fieras, ha creado, todavía la gloria, o sea la complacencia y admiración del triunfo por el triunfo mismo. La ideología pacifista es, pues, contraria a dicha índole (La patria fuerte, p. 23).

La guerra está en el centro de la política lugoniana. Parafraseando a Carl von Clausewitz podría decirse que la política no es en Lugones sino la continuación de su guerra por otros medios; una guerra ininterrumpida que no admite treguas ni compromisos legales ${ }^{6}$. En un informe confidencial destinado al gobierno del general José E. Uriburu, Lugones escribe hacia 1930: "Toda revolución que se paraliza en el legalismo y en la burocracia dejándose agredir en vez de atacar, está perdida”7.

6 "War", escribe Clausewitz en su clásico tratado sobre la guerra, "is not merely an act of policy but a true political instrument, a continuation of political intercourse, carried on with other means" (On war, tr. M. Howard \& P. Paret, Princeton University Press, Princeton, 1976, p. 87).

7 "Informe confidencial destinado al gobierno de José E. Uriburu", Crisis, 1974, núm. 14, p. 21. 
Tomar las armas, salir a la calle. El combatiente infatigable que fue Lugones proyecta una y otra vez sobre el espacio público su guerra privada. El 16 de mayo de 1932, el diario de Federico Ibarburen transcribe una conversación con el Lugones fascista, ya entonces, "profeta de la hora de la espada":

Yo había pretendido una vez, en tiempos del gobierno provisional [escribe Ibarburen en boca de Lugones] constituir alrededor de tales núcleos patrióticos pequeñas minorías aguerridas. Intenté en varias oportunidades despertar en ellas la conciencia del peligro para, de tal manera, probar su CAPACIDAD DE ACCIÓN... En cierta ocasión propuse a un grupo de "legionarios" salir a la calle a quemar "La Vanguardia", que había publicado un editorial injurioso... contra las autoridades de la REVOLUCIÓN. Nos jugaríamos todos por igual en la patriada... ${ }^{8}$

La continuidad del discurso de la guerra que se enuncia en Lugones trasciende el orden de la figuración retórica. Relato performativo, esta guerra-discurso es la afirmación autorreferencial de la identidad del combatiente que allí se enuncia, del presente donde se encuentra como campo de batalla, y del enunciado en el que se constituye como acto de guerra. El discurso lugoniano postula solamente la posibilidad de decir la guerra para mantenerse en ella al interior de un orden nacido en la batalla. Producto de ese discurso el poeta soldado toma la palabra y combate. No hay palabra que no sea de guerra. La palabra soporta la guerra y la guerra se mantiene, se contiene, al interior de la palabra. La guerra no es solamente aquello que se habla en los textos lugonianos (el tema), sino también aquello que los hace hablar, que habla en esos textos (la forma) ${ }^{9}$.

La guerra construye en los textos lugonianos un relato que como tal no aparece en ninguna parte, pero que, al mismo tiempo, Lugones no dejó una y otra vez de narrar; una estructura que no es anterior a sus textos sino su resultado, pero que, retrospectivamente, los hace posibles y necesarios. Como sostiene Carl von Clausewitz, en su "forma simple" toda guerra es un duelo ${ }^{10}$. El carácter absoluto que adquiere ese duelo en

8 Orígenes del nacionalismo argentino 1927-1937, Celsius, Buenos Aires, 1969, p. 107.

${ }^{9}$ Cf. André Glucksman, Le discours de la guerre, Grasset, Paris, 1967.

10 "War is nothing but a duel on a larger scale -apunta CLAusewiTzcountless duels go to make a war, but a picture of it as a whole can be formed by imagining a pair of wrestlers. Each tries through phsysical force to 
Lugones constituye en su obra un principio de unificación formal. Guerra total, el duelo que es la guerra lugoniana involucra al sujeto, a sus textos y al espacio social que los acoge generando el lugar de encuentro formal que no jerarquiza determinaciones entre estas tres instancias cuya conjugación define el objeto de la crítica literaria. El sujeto es actor en esta guerra que lo constituye como tal. La guerra está narrada por el sujeto en unos textos que son, a su vez, armas en un combate social que los trasciende, pero que, al mismo tiempo, transcurre al interior de su forma. La sociedad en Lugones no sólo es arena de combate sino parte interesada en la contienda en que se bate su paladín, en tanto que allí, en sus textos, se juega su destino. Leer a Lugones exige enfrentar a esta violencia que abrumadora, ineludible, y obscena por momentos, destila su escritura. ¿Qué es lo que explica y exige esta violencia? ¿Cuál es su lógica y cuáles sus intensidades? ¿Quiénes se enfrentan en este combate? ¿Cuál es el desarrollo histórico de esta batalla sin fin?

\section{EL “Yo" HEROICO Y SU PROGRAMA}

La escritura lugoniana es una escritura no sólo desde el yo sino también por el yo. Marca del exceso que identifica todo enunciado lugoniano, hablar de la violencia y la guerra en Lugones exige de entrada, y sobre todo, hablar del estatuto del yo. Porque lo que se juega, lo que está en juego en la batalla que narran sus textos, es el estatuto del sujeto del enunciado de su discurso de la guerra: un yo ideal narcisista que carga con las faltas o "pecados" que definen, según George Dumézil11, a la figura mítica del guerrero: extrema ambición, soberbia, orgullo, euforia polémica y la libertad impredecible de su conducta. Un yo hipertrofiado, una figura autoritaria que no hace sino afirmar una y otra vez su propia y exclusiva verdad: su yo. Un personaje de pura exterioridad, un ser de una pieza, carente de secreto o intimidad, que no se sostiene sino en su propio enunciado. Un yo, en palabras del propio Lugones, "excesivo,

compel the other to do his will, his inmediate aim is to throw his opponent in order to make him incapable of further resistance", On war, p. 75. Sobre el concepto de "forma simple" remito a André Jolles, Formes simples, trad. A. M. Buguet, Éds. du Seuil, Paris, 1972.

${ }^{11}$ Heur et malheur du guerrier, Flammarion, Paris, 1985, pp. 72-130. 
imprudente, impertinente, contradictorio y desagradable”, así es como se presenta el poeta en el teatro Rivera Indarte de Córdoba en abril de 1915. "Rebelde a toda soberanía... Peligroso para el orden, celoso de mi libertad con uñas y dientes: como una fiera; caprichoso de la brisa como un pájaro..." (Nuevos estudios helénicos, p. 221). Un yo absoluto que en su vocación monumental se

siente grande y se imagina al mundo una inmensa morada; palacio en que es el rey omnipotente que rige, y quiere, y manda

(Primeras letras, p. 14).

Un yo despótico, dispuesto, como manifiesta Lugones, "a proclamar el más intransigente neronismo intelectual" ya que, "dentro del presente estado social, nada revela tanto la personalidad como el abuso y mejor aún la tiranía"12.

Único e indivisible, el yo heroico lugoniano se define como un personaje autotélico y autosuficiente que se "basta sin faltas ni sobras". Un ser autónomo, plenamente soberano, condenado en sus extremos a la más absoluta soledad. "Fuerte y solo: he aquí la situación del caballero andante" (El payador, p. 132). "Solos y pocos hicimos en tiempos de la gloria y del honor las mejores cosas", apunta Lugones en Acción (p. 42). En los extremos en los que se postula, la soledad de la que hace gala el guerrero lugoniano debe leerse como misantropía, como desprecio y rechazo del semejante. Alcestes, el misántropo de Molière, no es sólo un modelo clásico para este yo desdeñoso y orgulloso, sino una referencia confesa en los textos lugonianos: "Me entiendo mejor con Alcestes que con Almaviva", escribe el joven Lugones hacia $1898^{13}$.

La violencia es, junto al delirio de grandeza y a la libidinización del yo, uno de los caracteres que definen según Freud a toda personalidad narcisista ${ }^{14}$. La misantropía, la megalomanía, la infatuación ideal del yo, dibujan sin duda en el guerrero lugoniano el perfil de una figura narcisista. Ahora bien, hacer del guerrero lugoniano un Narciso heroico no es, en todo ca-

12 "La moral del arte", La Montaña, 1 de junio de 1897, p. 4.

13 "Licantropía", Philadelphia, III, 7 de septiembre de 1898, p. 84.

14 "Introducción al narcicismo", Obras completas, trad. L. López-Ballesteros y de Torres, Biblioteca Nueva, Madrid, 1981, t. 2, pp. 2017-2033. 
so, interpretar a Lugones sino citarlo. En su "Laudatoria a Narciso", el poeta escribe:

Tomaré de ti ejemplo en firmeza i constancia De corazón mis manos lavaré en tu fragancia, Para oficiar el rito que alumbra la amatista Con su ojo minervino sobre un altar ipsuista... Diré cómo moriste de amarte en el completo Deleite de la consunción, i diré el secreto Que tus muslos ocultan al placer fornicario... Oh, dame las propicias lumbres del Arte sacro I así mi carne pueda fijar tu simulacro... I así envuelva mi cuerpo, de amor enajenada Como un larga cinta de seda mi mirada

(Las montañas del oro, p. 83).

Guerra y épica han constituido históricamente un binomio inseparable. La disposición guerrera hace para Carlyle atributo fundamental de todo "Gran Hombre"15. Emerson, por su parte, define el heroísmo como "the state of the soul at war" 16. Guerra y épica no son en Lugones sino variables de un mismo proyecto: la construcción de un mundo y una subjetividad heroicas en su voluntad de absoluto. Sin duda la épica constituye un tema recurrente en la escritura lugoniana. Los títulos de sus libros lo anuncian una y otra vez: Las industrias de Atenas, El ejército de la Ilíada, Un paladín de la Ilíada, La funesta Helena, Una dama de la Odisea, Héctor el domador, Estudios helénicos, Nuevos estudios helénicos. Ahora bien, más que un "tema de época" susceptible de una lectura historicista, o un repertorio de contenidos ideológicos a estudiar conforme los parámetros de la historia intelectual, la épica es en Lugones conjuntamente una

${ }^{15}$ El héroe en sus múltiples posibilidades (divinidad, profeta, poeta, sacerdote, hombre de letras o rey) tiene para Carlyle como denominador común su capacidad guerrera: "The Poet —escribe- who could merely sit on a chair, and compose stanzas, would never a stanza worth much. He could not sing the Heroic warrior, unless he himself were at least a Heroic warrior too... Napoleon has words in him wich are like Austerlitz Battles". Y agrega más adelante, describiendo el lenguaje bélico de ese "Gran Hombre" que fue Lutero: "His words are half-battles. They may be called so. They essential quality of him was, that he could fight and conquer; that he was a right piece of human valor" ("On héroes, hero-worship and the heroic in history", en Thomas Carlyle. The complete works, Peter Fenelon Collier, New York, 1987, t. 12, pp. 307 y 364).

16 "Heroism", en Complete writings, WM. H. Wise, New York, 1929, p. 202. 
poética, una política y una pasión. En todo caso, un proyecto formal de identidad que buscó, por un lado, imprimir en la realidad la imagen absoluta de su yo narcisista, y por el otro, y al mismo tiempo, actualizar en todo tiempo y lugar las coordenadas que definen al género y al mundo heroico: la "inmanencia del sentido", al decir de Lukács ${ }^{17}$; la unicidad, el monologismo, un mundo eterno en su carencia de alteridad, en palabras de Bakhtin ${ }^{18}$. Las preguntas lugonianas: ¿Cómo ser un héroe? ¿Cómo construir el ideal de un mundo épico a la medida de sus sueños de absoluto?

Respuesta a estas interrogantes, la guerra construye en Lugones la escena fundadora del universo épico del escritor, del héroe que quiso ser el poeta y de la epopeya que pretendieron ser sus textos. Motor formal de su escritura, la guerra constituye lo que podemos llamar el "modo de producción" épico lugoniano; dentro de la batalla que se libra en sus textos se proyecta la imagen heroica de ese "Paladín de la Ilíada" que quiso ser el poeta; son alternativas del combate las que otorgan visos de posibilidad a ese absurdo sueño de absoluto que es la épica en Lugones.

Hacia 1900, en una serie de artículos programáticos publicados por la revista Philadelphia ("Nuestro método científico", "Objeto de nuestra filosofía", "Nuestras ideas estéticas"), Lugones presenta los paradigmas de su empresa épica de identidad, los lemas de guerra de ese yo omnipotente y desmesurado: uno, todo, forma, sentido. Más allá del orden del "fenómeno" y la contingencia de la vida, el objeto de la filosofía lugoniana no es otro que "el descubrimiento de la ley fundamental del pensamiento, cuya ley... el principio de identidad, se formularía

17 George Lukács define el mundo épico, propio de las llamadas "civilizaciones integrales", como un espacio unitario "complete in meaning -in sense - and complete for the senses". Se trata de una "época feliz", apunta Lukács, plena de sentido, ajena a la duda que exige la reflexión filosófica y abre la distancia entre el hombre y el mundo exterior (Theory of the novel, tr. A. Bostock, The MIT Press, Cambridge, MA, 1982, pp. 29-39).

18 En contraste con el dialogismo y la apertura al discurrir temporal propio de la novela, Bakhtin define el mundo épico como un espacio clausurado a todo cambio o devenir, congelado en un pasado eterno. El universo épico, sostiene Bakhtin, "is as closed as a circle, inside it everything is finished, already over. There is no place in the epic world for any openendedness, indecision, indeterminacy" (The dialogic imagination, tr. C. Emerson \& M. Holquist, University of Texas Press, Austin, 1987, p. 16). 
así: «toda cosa es idéntica a sí misma»"19. Ajeno a cualquier lógica experimental, a cualquier contacto con una realidad exterior a sus propios postulados, el "método científico" que afirma la empresa heroica lugoniana tiene por objeto "buscar principios indiscutidos y comunes a todos los estados intelectuales, vr. gr. la unidad, el espacio, el punto matemático, la forma... verdades indiscutidas e indiscutibles" 20 . Una vocación unitaria y monológica, un deseo exasperado y, por momentos, exasperante de forma y de sentido, que ese "soñador del absoluto" que fue Lugones afirma de forma clara y concisa: "Queremos religión, queremos que se nos afirme el absoluto" 21 , escribe el poeta. Absoluto, totalidad, unidad, en el contexto que propone este programa totalizante y, por qué no decirlo, totalitario de identidad, la misión del artista no puede ser otra para Lugones que "restaurar la unidad sustancial del Todo"22.

"El heroísmo se confunde con el ideal", escribe Lugones, "asumir un ideal es ponerse en situación de heroísmo" (Primeras letras, p. 35). Especular y redundante, la escritura lugoniana no hace sino construir el ideal de un mítico imaginario heroico que, a su vez, no hace sino repetir hasta el hartazgo los paradigmas de orden, sentido y totalidad que animan y definen a su yo monumental. Grecia, Ruskin y el gótico, la Argentina transhistórica de El payador y La guerra gaucha, un mundo pleno de sentido que remite a lo que Lukács ha llamado las "civilizaciones integrales". El ideal neoplatónico de "verdad-bien y belleza" que postulan sus manifiestos estéticos y las formas orgánicas que lo materializan: la catedral, el poema épico, el templo dórico y el canon de Fidias. Un modelo total y absoluto de identidad que en lo subjetivo remite a los númenes del mundo heroico lugoniano, los padres fundadores de la patria, Sarmiento, Ameghino y Roca, a los héroes homéricos, a los héroes solares de Prometeo, a Rosas, "hermoso tirano de los ojos azules" (Primeras letras, p. 74) o Uriburu y Mussolini para el Lugones fascista. Un espacio homogéneo, homoerótico habría que decir, poblado de "ejemplares humanos superiores", "prototipos de belleza, de bien y de verdad" (El payador, pp. 23, 27); p. 793 .

19 "Objeto de nuestra filosofía”, Philadelphia, XII, 7 de junio de 1900 ,

20 "Nuestro método científico", Philadelphia, II, 7 de agosto de 1900, p. 56.

21 "Acción de la teosofía”, Philadelphia, VI, 7 de diciembre de 1898, p. 169.

22 "Nuestras ideas estéticas", Philadelphia, V-VI, 7 de noviembre de 1901, p. 159 . 
hombres hermosos, "dotados" de "atributos" viriles: espadas, sables, lanzas, monolitos. Un ámbito monumental animado por una pasión, "la pasión de lo inmenso" (Primeras letras, p. 20), que diría el poeta. Un ideal de desmesura que remite a un mundo de alturas, de cimas coronadas por cóndores, a la orografía de sus títulos: La montaña, Las montañas del oro; a los proyectos arquitectónicos faraónicos dignos de Albert Spier que Lugones propone para la celebración del centenario; o a esa patria absoluta, esa "argentina potencia" que fabulan sus ensayos políticos. Este es el espacio familiar de los ancestros esenciales que cantan sus poemas. "Los Lunones del gran castillo" que prologan Lunario sentimental. "Los hombres", "Los antepasados" que cantan sus Odas seculares y sus Poemas solariegos, "la familia de bronce" (Primeras letras, p. 77) que diría Lugones. Una galería de grandes hombres que compone lo que con Freud podríamos llamar la "novela familiar" del héroe lugoniano: un mito que articula imaginariamente en el sujeto la genealogía de una identidad ${ }^{23}$. Un relato, en Lugones, poblado no sólo de grandes padres, sino también de madres heroicas: la madre patria, la comarca natal, la "Pacha mama", "la antigua madre de los cerros" en La guerra gaucha (p. 29), o las matronas, ilustres madres y compañeras de los héroes, Paula Albarracín, madre de Sarmiento o Penélope, "dama de la Odisea" en sus Estudios helénicos. En todo caso, el sueño de un mundo que en su armonía indiferenciada carece incluso de sexo y de deseo. Arte, sociedad, sexo, omnipresente, un modelo total de identidad, la imagen absoluta de un mundo inmediato, idéntico a sí mismo por el acto de excluir de él toda diferencia que condensa y repite la imagen del yo guerrero y narcisista.

\section{EL “otro” MONSTRUOSO Y LA PERSECUCión DE LA IMPUREZA}

Toda guerra exige un enemigo. El guerrero lugoniano no está solo en el campo de batalla. A su lado, al otro lado de esa frontera que la escritura lugoniana traza y retraza en un binarismo obsesivo, encontramos al otro, al enemigo. El otro en Lugones es siempre un enemigo y el enemigo del héroe guerrero lugoniano es siempre un monstruo. Doble especular, objeto de ca-

23 S. FrEUd, "La novela familiar del neurótico", en Obras completas, t. 2, pp. 1361-1363. 
racteres negativos, enemigo absoluto, el monstruo es en el discurso lugoniano una figura metafórica que condensa todo aquello que se opone al despliegue de la empresa heroica del escritor. A la pureza del héroe el monstruo opone la impureza más abyecta, a lo grandioso lo miserable, al orden el desorden, a lo completo lo inacabado, la mezcla y el exceso, al todo el notodo. Pueden tratarse de los monstruos hembras de origen lunar de Prometeo, de la mujer y su deseo, "las potencias ciegas de la sexualidad representadas por la mujer lasciva" (Prometeo, p. 18), de la novela y el doctor Sicardi ${ }^{24}$, de la vanguardia y el futurismo, "el imperio del mamarracho" para Lugones ${ }^{25}$, de un defecto corporal, de una mancha, del tango, "reptil de lupanar", de un adversario político o de los inmigrantes, "cómplices mulatos y sectarios mestizos" en El payador (pp. 92, 15). Todos y todo pueden ocupar en la escritura lugoniana el lugar y la función del monstruo. Producto y productor de una crisis en el ideal narcisista de identidad que postula el guerrero lugoniano; cualquier diferencia, cualquier alteridad, adquiere en sus textos caracteres monstruosos: una falta de ortografía, un libro mal colocado, el óxido sobre la espada o una chorrera sobre un cañón. En resumen, "un conjunto enteramente opuesto a la idea de gloria pura y serena que el monumento", el ideal decimos nosotros, "debe encarnar" (Piedras liminares, p. 216). Una definición posible, leemos en Lugones:

la correlación de las formas es un resultado de la adaptación al medio, ley primordial a cuyo acatamiento queda subordinada... la adquisición de la estabilidad orgánica. Fuera de estas condiciones, el ser es un monstruo. Establezcamos todavía como postulado, que el monstruo adolece siempre de fealdad, por falta esencial de armonía en sus formas (ibid., p. 52).

${ }^{24}$ Aludo a Francisco Sicardi, autor de El libro extraño, una de las primeras novelas argentinas. A propósito del carácter monstruoso que adquiere Sicardi y su novela en el imaginario heroico lugoniano véase, LEOPOLDo LuGONES, "Francisco Sicardi", Buenos Aires, 9 de abril de 1899, en Primeras letras, pp. 113-114.

${ }_{25}^{25}$ Sobre la aversión lugoniana a los movimientos estéticos de vanguardia remito a sus crónicas periodísticas escritas desde París publicadas en $\mathrm{La} \mathrm{Na}$ ción y Sarmiento: "El triunfo de la antiestética I", La Nación, 28 de noviembre de 1911, p. 11; "El triunfo de la antiestética II", La Nación, 5 de diciembre de 1911, p. 8; "El triunfo de la antiestética”, La Nación, 14 de diciembre de 1911, p. 16; "El imperio del mamarracho", Sarmiento, 18 de mayo de 1912, pp. 1 y 3; "El imperio del mamarracho II", Sarmiento, 26 de mayo de 1912, pp. 1 y 3. 
En su multiplicidad anamórfica, el monstruo lugoniano escapa a cualquier taxonomía. Otro perverso, íntimo e inmediato, el monstruo es una diferencia radical que hace imposible trazar los límites de una identidad estable o construir como correlato o en oposición el campo de lo propio. Absoluta alteridad, el monstruo lugoniano subvierte en su extrema diferencia incluso los límites del lenguaje, aquellos que, a su interior, permiten designar lo otro como otro y lo idéntico como tal. Más allá de cualquier posible definición, la diferencia invoca siempre en Lugones la dimensión freudiana de lo siniestro, de lo Unheimlich, de aquello que, próximo y lejano, familiar y absolutamente extraño, subvierte cualquier posible lógica oposicional $^{26}$. Interior y exterior al campo de identidad épico, el otro monstruo es siempre en Lugones una "doble amenaza" (Acción, p. 7), un objeto "ext-imo", exterior e íntimo a la vez, transgresor de cualquier límite o frontera.

Otro impuro, el monstruo lugoniano remite a lo que Julia Kristeva ha definido como una diferencia abyecta, es decir, otredad productora de una crisis en el ideal narcisista de identidad que postula el guerrero lugoniano ${ }^{27}$. Manchas, lepra, en sus extremos lo escatológico, alteridad inasimilable que invoca el ámbito de lo sagrado, que inscribe su diferencia en el espacio de lo excluido y separado del orden socio-simbólico comunitario; el monstruo lugoniano es una otredad que remite a los límites más elementales y primarios de una identidad, a aquello que en una cultura protege la ley del tabú, de lo innombrable e intocable, a aquello que, a falta de palabras, despierta asco y repulsión. El brillo omnipotente del héroe, y de su ideal épico de identidad, oculta en los textos lugonianos la presencia opaca, oscura, del monstruo, pero allí donde la heterogeneidad deja leer por exceso o por defecto la marca de una carencia en la superficie del todo, su escritura bascula mostrando sin transición su reverso: el nadir del cenit heroico, la impureza abyecta de la diferencia más absoluta: el monstruo.

26 S. Freud, "Lo siniestro", en Obras completas, t. 3, pp. 2483-2507.

27 Pouvoirs de l'horreur. Essai sur l'abjection, Éds. du Seuil, Paris, 1980. En lo relativo a la abyección remitimos también a George BATAILle, "L'abjection et les formes misérables", en Oeuvres complètes, Gallimard, Paris, 1970, t. 2, pp. 217-221. Sobre el problema de la impureza, véase VLADIMIR JankéLéVITCH, Lo puro y lo impuro, trad. J. L. Checa, Taurus, Madrid, 1990; y también Mary Douglas, Purity and danger. An analysis of concepts of pollution and taboo, Frederic A. Prager, New York-Washington, 1966. 
"El astro... vive de brillar", escribe Lugones, "y cuando deja de hacerlo abandona su condición de astro por la oscuridad de la roca" (Historia de Sarmiento, p. 91). Cuando esto sucede aparece en sus textos el monstruo,

produciéndole unas caries que le dará todo el aspecto del cascote. Aquéllo además de ruinoso, se volverá repugnante como una afección sórdida. Degenerará en la negrura tuberculosa de una especie de cáncer: la podredumbre cualitativa que el vulgo asigna a tal piedra por definición. Será una decrepitud llagada, en comento glorificador de la dulce hiperdulia, que lleva consigo, como atributo eminente, la blancura de la salud (Piedras liminares, p. 184).

Exceso, desmesura, goce de la palabra, erotismo de la lengua. La presencia del monstruo introduce en la escritura lugoniana el surplus de una carga energética que escapa al orden del discurso. El efecto Lugones, ese tono convulsivo inconfundiblemente suyo, es resultado de la intensidad, de la violencia espasmódica, de la angustia que desata en su escritura la presencia del monstruo. La profusión verbal, la saturación simbólica, el horror físico, el asco, que despierta el adversario en la batalla, hacen evidente el combate que la escritura lugoniana libra, en su intento desesperado por capturar simbólicamente una diferencia que escapa a sus posibilidades de representación.

Guerra y discurso paranoico se superponen en la escritura lugoniana. Próximos a los famosos delirios del presidente Schreber ${ }^{28}$, los textos lugonianos son el teatro constante de una persecución: el combate constante entre el yo narcisista, sujeto de su discurso guerrero, y esa otredad monstruosa e impura que lo acosa desde los límites de la representación. A la soledad del guerrero, el monstruo opone su presencia masiva e invasora. Son las "injurias" y "diatribas" que los mediocres,

${ }^{28}$ Memoirs of my nervous illness, tr. I. Malcapine \& R. A. Hunter, Harvard University Press, Cambridge, MA, 1988. Caso clásico de paranoia, el relato de Schreber ha sido objeto de multitud de interpretaciones. Desde el psicoanálisis véase: Sigmund Freud, "Observaciones psicoanalíticas sobre un caso de paranoia (Dementia paranoides) autobiográficamente descrito", en Obras completas, t. 2, pp. 1487-1528; JACQUES LACAN, El seminario. Libro 3: Las psicosis, trad. D. Rabinovich, Paidós, Buenos Aires, 1993 y "De una cuestión preliminar a todo tratamiento posible de la psicosis", Escritos 2, trad. T. Segovia, Siglo XXI, México, 1985, pp. 513-564. Para una lectura no psicoanalítica del caso Schreber, remito a Elías Canetti, Masa y poder, tr. H. Vogel, Alianza Editorial, Madrid, 1987. 
"los gusanos de la gloria" (Historia de Sarmiento, p. 92), "los térmites de la fama" (Primeras letras, p. 68), ese monstruo que es la opinión pública para Lugones, "comedor de cadáveres y apedreador de estatuas" (ibid., p. 69), proyecta sobre la figura monumental de los grandes hombres. Es la turba, "los rebaños electorales de mestizos, el eterno elemento servil del caudillaje" (Historia de Sarmiento, p. 257) que invade la ciudad o "la invasión cosmopolita", "el peligro exterior" (Acción, p. 25) que asalta La patria fuerte. "Los caballos de Abdera", relato incluido en Las fuerzas extrañas que narra la sublevación de una masa lujuriosa de brutos salvajes que asalta desde la periferia el recinto de una ciudad amurallada, constituye, quizás, la escena más lograda en la escritura lugoniana de esta reiterada geografía paranoica que construyen sus textos.

\section{EL COMBATE POR EL "YO"}

Yo-otro, puro-impuro, política, literatura, sexo; la guerra recorta el universo lugoniano trazando un antagonismo extremo que recorre en su conjunto todo el imaginario del escritor. Causa y razón última de la guerra, más allá de cualquier abstracción, sin embargo, lo que está en juego en el combate que reiterados narran los textos lugonianos es la supervivencia de su yo hipertrofiado. Tautológico, ser de pura exterioridad carente de cualquier contenido, el yo heroico lugoniano se define como pura propiedad: "Y-yo", apunta Lugones en su "Diccionario portátil para simbolista", "no todos los hombres poseen esta prenda preciosa. Muchos hay que en vez de tener yo tienen usted"29. Tener un yo o no tenerlo, ése es el problema que enfrenta el héroe lugoniano. "La soberanía consiste ante todo en poseerse" (La grande Argentina, p. 42), escribe Lugones "Cuando digo «Yo» afirmo, en efecto que soy dueño de mí: condición primordial de la existencia consciente". Causa sui, ser absolutamente soberano, la afirmación última de esta soberanía hace del yo heroico lugoniano un personaje exterior al orden socio-simbólico comunitario, una figura al margen del contrato social. Próximo al "anarca" en Ernest Jünger, o al "único" de Max Stirner ${ }^{30}$, el héroe

${ }^{29}$ BAAL, 1959, núms. 91/92, p. 168.

30 A propósito del "anarca", dice Jünger: "Encarna más bien el punto de vista de Stirner, el autor de El único y su propiedad; es decir, que es lo 
lugoniano, "sin amo ni ley", es un sujeto que crea su propia ley: "Conforme mi inveterada costumbre", escribe Lugones, "yo soy el autor de mi deber, de mi beligerancia y de mi estrategia... Yo me hago mi ley, me la doy y me la quito. Si tengo alguna autoridad de eso me viene" (Mi beligerancia, p. 10). Conciencia absoluta de sí, el yo heroico lugoniano afirma una ley y una moral privadas de Señor y de guerrero, lo que Hegel ha conceptualizado en la Fenomenología como una "ley del corazón" 31 : un deseo no mediado que proyecta sobre el mundo la imagen del sujeto que lo encarna en la figura de su yo. Megalómano, infatuado yo ideal, que niega el orden del mundo, el guerrero lugoniano remite al interior de su propio discurso a la figura del loco despótico. A propósito de la "enfermedad mental del despotismo" Lugones escribe hacia 1917 una imagen que muy bien podría ser su autorretrato:

La enfermedad mental llamada despotismo, presenta características constantes que permiten su determinación histórica. Todas ellas resúmense en una preponderante: la inmoralidad... El in-

único. Stirner dice: «Nada prevalece sobre mí». El anarca, de hecho, es el hombre natural. No lo corrigen más que las resistencias con las cuales choca cuando desea extender su voluntad más lejos de lo que se lo permiten las circunstancias generales. En su ambición por realizarse, encuentra forzosamente ciertos límites; pero si estos límites no existieran, tendría una expansión indefinida; es, por ejemplo, el destino de los Césares, o también el del niño que hace lo que le place" (Julien Herner, Conversaciones con Ernst Jünger, F.C.E., Buenos Aires, 1990, p. 72).

31 Hegel define la "ley del corazón" como un "orden natural" pero universal que se opone al "orden reinante", al orden mundano, que es considerado por la conciencia como una apariencia sin fundamento. La guerra es, para Hegel, el resultado necesario de la afirmación de la "ley del corazón": "Lo universal que está presente sólo es... una resistencia universal y una lucha de todos contra todos... Así pues lo que parece ser un orden público no es sino este estado de hostilidad universal..." (Fenomenología del espiritu, trad. W. Roces, F.C.E., México, 1993, p. 223). Imponer su propia ley, no será para la conciencia heroica sino generar un mundo a su propia imagen. "Si el mundo no es más que una objetivación exteriorizada de mi yo", escribe el joven Lugones hacia 1897, "claro es que poseo el derecho absoluto de transformarlo a mi manera. Si la armonía que resulta como consecuencia de las distintas objetivaciones, cuya síntesis me da la idea del mundo no me satisface hoy, la abandono inmediatamente. Sólo tengo, pues una moral mía, totalmente diversa de la de los demás. La lógica está dentro de mí mismo yo soy el único que puede cambiarla" ("La moral del arte", p. 4). 
moralista... está mentalmente enfermo... Su lógica... procede del absoluto egoísmo, o hipertrofia de la personalidad, que es común a todos lo enajenados... El egoísmo del enajenado engendra, con su exclusión de afección y de lógica, el aislamiento compasivo u hostil, según el carácter de la enajenación; pero en todos los casos, infinitamente orgulloso... La presunción, la megalomanía, el misticismo, todas o casi todas las formas de enajenación, resuélvense en una vaguedad grandiosa que tiene como centro al enfermo cuya personalidad viene a constituir la única cosa importante del universo... El déspota es un enajenado... Créese siempre agente divino para juzgar y castigar; con lo que se le convierte en dios su propio desmesurado egoísmo ( Mi beligerancia, pp. 173-175).

Batalla por el yo y su ideal mítico-heroico de identidad, la guerra constituye lo que desde el psicoanálisis y con Lacan podríamos definir como el "estadio del espejo" del héroe lugoniano: una "matriz simbólica en la que el yo (je) se precipita en su forma primordial, antes de objetivarse en la dialéctica de identificación con el otro"32. Defensora de la Gestalt primaria de ese yo, de la imago heroica del sujeto y, por otro lado, "furiosa pasión" identificadora que busca imprimir en la realidad su imagen despótica, la violencia constituye en Lugones, como en Lacan, una tendencia correlativa a la identificación narcisista del sujeto.

Fascinación con la propia imagen, deleite especular de un yo narcisista, en el punto de partida de la batalla, la escena utópica que construye la guerra lugoniana coloca al héroe y a su yo absoluto en las alturas, en el centro de un sistema solar, ajeno a cualquier contradicción, a cualquier otredad que perturbe su brillo:

Ventura grande es para la humanidad ese carácter expansivo de las glorias que brillan con la inmutabilidad de un sol cuando son verdaderas. Las miserias, por el contrario se arrastran en las tinieblas como víboras, y cuando alguna vez alzan la cabeza con la insolencia de la infamia ensoberbecida su misma deformidad las aparta todas las miradas (Primeras letras, p. 19).

32 JaCQues LACAN, "El estadio del espejo como formador de la función del Yo [je] tal como se nos revela en la experiencia psicoanalítica”, en Escritos 1, trad. T. Segovia, Siglo XXI, México, 1990, pp. 86-93. 
La guerra lugoniana no tiene por objeto más que preservar la pureza, la autonomía, el carácter soberano que exige al escritor mantener el estatuto heroico de su yo narcisista; si, como dice Lugones, "los hombres tienden con irresistible impulso a esas anulaciones vergonzosas del $y o^{\prime \prime} 33$, la tarea del héroe no puede ser otra que exaltar omnipotente ese yo que se quiere heroico. En el relato paranoico que construyen los textos lugonianos, la figura del monstruo cuestiona al héroe guerrero en la batalla la propiedad e integridad de su yo, que soporta la identidad del poeta-soldado y del cuerpo que encarna en el combate su ideal épico de identidad. Definido el héroe, el ataque del monstruo es inmediato:

Apenas una frente empieza a descollar empurpurándose de aurora y coronándose de sol; apenas una mano salida de la multitud se cierra sobre las riendas de los acontecimientos... el pululante enjambre de larvas que hormiguea entre los estiércoles del establo social, endereza sus antenas, eriza sus pelos venenosos y exclama: ¡qué buena presa! (Primeras letras, p. 68).

El objetivo del monstruo no es otro que someter la altivez de la figura del héroe, fracturar su "dureza", partir su "rigor", humillar su orgullo soberano:

El objeto capital de sus ataques es la vértebra. Contra ese pequeño eslabón de hueso dirigen toda su rabia. Qué placer cuando han conseguido doblarla, laminarla, flexibilizarla, iniciando sobre las espaldas del fuerte la curvatura de una humilde reverencia (loc. cit.).

En la escena castrante que diseña la batalla en los textos lugonianos, el frenesí de horror y angustia que desata la presencia de la diferencia es proporcional a la naturaleza de su amenaza. Como en "el estadio del espejo" estudiado por Lacan, en su ruptura de ese todo épico que se pretende "orgánico", el monstruo agita en la escritura lugoniana el fantasma de la fragmentación del cuerpo ${ }^{34}$. Frente a la soberanía absoluta que pro-

33 "La moral del arte", p. 4.

${ }^{34}$ El fantasma del "cuerpo fragmentado", sostiene LACAN, "se muestra regularmente en los sueños, cuando la moción de análisis toca cierto nivel de desintegración agresiva del individuo. Aparece entonces bajo la forma de miembros desunidos y de esos órganos figurados en exoscopia... esa forma se muestra tangible en el plano orgánico mismo, en las líneas de fra- 
pone y exige la condición épica, el monstruo, en ese combate cuerpo a cuerpo que es la guerra lugoniana, amenaza al héroe con posibilidad humillante de la posesión física, con el horror de la desmembración corporal, con la pérdida de unos "atributos" que lo definen como tal, en el límite con la castración. Ante una amenaza así, escribe el joven Lugones en 1917:

Los que somos jóvenes no podemos callar, así tengamos que sucumbir asfixiados, demolidos, descoyuntados, reventados en una asquerosa fornicación de escrutinios. Es necesario... batirse... La guerra no puede ser defensiva, sino ofensiva porque la pocilga está en sedición y nos amenaza con una indigestión de bellotas. Los mediocres y los dóciles, sin declinar naturalmente su irremediable bajeza, intentan absorbernos en su glutinosa pasta, para tullirnos bajo la temperatura polar de un hermafroditismo tan degradante como inicuo... ofreciéndonos el balurdo de buen vivir, el cordel dorado con que se ahorcan las lenguas y se suprime las erecciones de la virilidad (Primeras letras, p. 66).

En el contexto que propone este combate: "La neutralidad", dice Lugones, "no cabe en un alma sana y viril, puesto que substantiva, por definición la carencia de sexo" (Mi beligerancia, p. 209). En la batalla el héroe confronta una heterogeneidad radical. A la pureza de una identidad que se pretende inmaculada, el monstruo opone la diferencia más abyecta. Es allí, frente a ese abismo que se abre en presencia del monstruo, donde se juega la identidad del yo heroico lugoniano y de su ideal épico de identidad. Ser un héroe y brillar como un sol o morir castrado y humillado entre los mediocres. Estos dos polos trazan los límites extremos entre los que discurre la guerra lugoniana. "Porque así son los resultados de la falibilidad humana", nos dice el poeta. "Reduce tu altura, montaña y te pisotearán las cabras, elévate mucho, y te envolverá la nieve" (Primeras letras, p. 140).

\section{LA LUCHA A MUERTE Y LA MÁQUINA DE GUERRA}

Cuando Lugones se suicidó en 1938, Macedonio Fernández dijo que "Lugones arriesgaba siempre vida y fortuna en todos

gilización que definen la anatomía fantasiosa, manifiesta en los síntomas de escisión esquizoide o de espasmo, de la histeria" ("El estadio del espejo", Escritos 1, p. 90). 
los gestos, inclusive los literarios" 35 . La muerte como horizonte define en el campo de batalla las condiciones e intensidad del combate que se libra en los textos lugonianos. Guerra mortal, sin duda, el espacio agónico que construye la batalla remite en Lugones al escenario hegeliano de la lucha a muerte ${ }^{36}$. A una lucha de puro prestigio y de dominio donde se mide y prueba la identidad absoluta de ese Señor guerrero que es el yo heroico lugoniano. Yo-otro, identidad-diferencia, vida-muerte, la guerra lugoniana construye lo que Clausewitz ha llamado una "oposición polar": un conflicto carente de cualquier posible mediación, una lucha en que la victoria de uno de los contrincantes exige necesariamente la derrota absoluta de su enemigo $^{37}$. Si al decir de Lugones, "en el candor del mármol cualquier peca es defecto de belleza y de solidez" (Estudios helénicos, p. 205), ser un héroe, conservar y defender ese ideal épico de identidad exige, en consecuencia,

conservar en todo momento la noble prenda del carácter, que no está permitido olvidar, porque ella es como el pudor y la fe: algo en que toda intransigencia resulta mancha: porque hay dos cosas inmaculadas sobre todo: los sables y las hostias. Y el arte que vale por ambos (Primeras letras, p. 57).

Lo blanco o lo negro entonces, la vida o la muerte, en la lógica del honor no hay compromiso ${ }^{38}$ : "toda intransigencia resulta mancha”. La vocación de absoluto que anima al yo heroico lu-

35 Emir Rodríguez Monegal, Borges por él mismo, Monte Ávila, Caracas, 1981, p. 189.

36 G. W. F. Hegel, "Autonomía y sujeción de la autoconciencia: dominio y servidumbre", Fenomenología del espiritu, pp. 113-121. Para un excelente comentario de la dialéctica hegeliana del siervo y del señor, véase Alexandre Kojève, Introduction a la lecture de Hegel, Gallimard, Paris, 1968, pp. 9-34.

37 A propósito del principio de polaridad Clausewitz escribe: "By thinking that the interest of the two commanders are opposed in equal measure to each other, we have assumed a genuine polarity... The principle of polarity is valid only in relation to one and the same object, in which positive and negative interests cancel one another out. In a battle each side aims at victory; that is a case of true polarity, since the victory of one side excludes the victory of the other" (On War, p. 83).

38 Sobre la lógica del honor y su función en la Grecia clásica véase JEAN Pierre Vernant, "La belle mort et le cadavre outragé”, en L'individu, la mort, l'amour. Soi-même et l'autre en Grèce ancienne, Gallimard, Paris, 1989, pp. 41-79. 
goniano no solo exige la guerra sino también parece prescribir un solo tipo de combate, la lucha a muerte, destino necesario del guerrero lugoniano, porque lo que allí se decide es su única posibilidad de ser: un héroe. La defensa de ese estatuto épico, la lucha por la vida, estimula al guerrero lugoniano, da sentido a la imperiosa persistencia de la lucha, a la necesidad de combatir que se manifiesta en su textos. En la circunstancia trágica de un mundo así constituido, no hay paz ni compromiso posible: "Nunca he pedido cuartel para mi verdad", escribe Lugones en El payador (p. 202).

En la lucha de dominio y prestigio que construye la escena de la lucha a muerte, donde se proyecta la figura del guerrero, las pasiones que desata el conflicto alimentan su escritura de combate. Esa cosa abyecta e impura que es el monstruo constituye el soporte último de la identidad del poeta soldado. Detonante de la batalla, el monstruo es lo que hace posible al héroe lugoniano. Saberse héroe exige hacer del otro un monstruo. El guerrero lugoniano es en el campo de batalla. Si la guerra y su discurso constituyen el "modo de producción" épico lugoniano, el monstruo es un signo de la productividad de ese discurso. "Conseguir un amigo es vulgar", escribe Lugones, "conseguir un enemigo es grande" (Primeras letras, p. 55). La máquina de guerra, la escritura lugoniana, funciona alimentada por esta contradicción interna. Sin monstruo, sin enemigo, no hay guerra, y sin combate, sin batalla, no hay héroe. “¿Cuántas cosas se han hecho en tres años!", escribe Lugones hacia 1897. "Ahí está el río de tinta para justificarlo. Campañas contra esto, contra aquello bien. Contra éste, contra aquél mejor" (ibid., p. 78). La presencia del enemigo hace posible ese "río de tinta" que es la escritura lugoniana y el discurso de la guerra que allí se enuncia. La identidad del yo monumental lugoniano no es sino el producto agónico de una batalla sin fin, con esa diferencia monstruosa que no lo deja vivir en paz, que lo hace posible en el combate. Inmanente a su despliegue en la batalla, en constante formación, el guerrero lugoniano y su proyecto épico de totalidad evolucionan sometidos a la dinámica bélica que les impone el asedio de este suplemento que es el monstruo lugoniano. No existe en Lugones un espacio de identidad épico puro, previo a la distorsión que exige el proceso de su constitución: la guerra y su discurso. "El requiescat in pace no existe al fin para el heroísmo" (Piedras liminares, p. 202), dice Lugones. El guerrero busca la guerra y se mantiene en el 
campo de batalla porque en el combate el monstruo administra al héroe lugoniano la prueba de muerte cuya superación lo consagra como tal. "A mí también me han herido", escribe el joven Lugones. "Los felices me han apedreado con sus sarcasmos, me han escupido sus balcones, me han crucificado por varios delitos de altivez. ¡Incendiar el árbol! Buen modo a obligarlo a que alumbre" (Primeras letras, p. 52). Las heridas de la lucha son bautismo de fuego para el guerrero lugoniano, el peligro de muerte de la batalla, su certificado de vida como héroe y como soldado.

\section{El GOCE DE LA DESTRUCCIÓN Y DEL DOMINIO}

El tono exasperado y lujurioso de la palabra lugoniana, la carga pasional de su escritura, es el producto del goce mortal, de la pasión negativa, que moviliza al yo guerrero en su constante batallar. El ideal épico lugoniano proyecta la figura del yo heroico como un ser replegado en sí mismo, carente de deseos, contenido en los límites de su propia identidad. Formarse como héroe exige, según Lugones, "domar la bestia, combatir el instinto" (Prometeo, p. 337), aprender a dominar el deseo, esa diferencia que nos descentra, que inscribe en nos(otros) la presencia de un otro. La educación militar, la construcción del héroe, tiene por objeto "formar la voluntad, ese instrumento de guerra tan necesario como la espada, por medio del único método eficaz: la moral práctica, o sea el arte primordial de saber mandarse y vencerse; la sistematización personal de la victoria" (Historia de Sarmiento, p. 21). Más allá del orden y la contención que impone la disciplina militar, la batalla es un espacio propicio para todo tipo de excesos. Más allá de la lógica de la defensa, el ataque es ley de vida del guerrero lugoniano: "Tal y como la vida del fuego es quemar, y la del capital es rédito", sostiene Lugones, "la ley vital de la guerra es la conquista. Los mismos guerreros no sabrían evitarlo" (Mi beligerancia, p. 190). El ataque supone en Lugones la violación de un interdicto, que proyecta al yo guerrero fuera de sus límites, en la descarga de una energía libidinal que apunta en su escritura, la consumación de un deseo de destrucción y de muerte.

Ajena a toda mediación que no sea la muerte, la batalla es escenario en Lugones de lo que Bataille no dudaría en llamar relación "erótica", es decir una relación no mediada con la di- 
ferencia ${ }^{39}$. Rompiendo con el orden de la disciplina militar, el guerrero primitivo que es el héroe lugoniano se libra en el combate al ejercicio de una violencia salvaje y brutal. Allí estalla ese "furor" del guerrero del que habla George Dumézil, el goce de una violencia ilimitada ${ }^{40}$ :

El héroe insultado, siente que en su magnanimidad de león palpita la índole. Entonces el sarcasmo vuélvesele careta feroz. Cierta fulguración de estrabismo trastórnale un instante los ojos con oblicuidad de puñalada. El chapaleo desdeñoso y enfático de su palabra, exagérase todavía para el epigrama brutal... [M]onta en una de sus célebres cóleras... como un descomunal paladín en su corcel de pura llama. Hay que verle, entonces... Aquello ármalo en guerra con las fuerzas que saca de adentro, dijérase que por condensación eléctrica. Las ideas vánsele erizando como una crin... El peligro es su costumbre y la cólera su belleza (Historia de Sarmiento, p. 21).

El prestigio y el rango heroico del guerrero, el pathos del poeta soldado, se manifiesta en la descarga que hace posible la batalla ${ }^{41}$. Producción negativa, pasión de muerte y destrucción, aquí radica el tono y el "secreto" de eso que la crítica ha

${ }^{39}$ El erotismo, trad. A. Vincens, Tusquets, Barcelona, 1988.

40 DumÉzil describe el furor en los siguientes términos: "S'agit-il d'une fureur transfigurante, d'une frénésie dans laquelle l'homme se dépasse au point de changer de comportement, parfois de forme, devient une sorte de monstre infatigable, insensible ou même invulnerable, infaillible dans son estoc et insoutenable dans son regard. Son apparition triomphante sur le champ de bataille est une sorte de démonophanie: rien qu'á le voir, rien qu'á a entendre son cri le adversaire este penetré de terreur, paralysé petrifié..." (Horace et les curiaces, Gallimard, Paris, 1942, p. 17). En la lucha, los guerreros, escribe DumÉziL, "doivent se mettre dans un état nerveux, musculaire, mental, qui multiplie et amplifie leurs puissances, qui les transfigure, mais aussie les défigure, les rend étranges dans le groupe que'ils protégent; et surtout, consacrés á la Force, ils sont les triomphantes victimes de la logique interne de la Force, qui ne se prouve qu'en franchissant les limites, mêmes les siennes, même celles de sa raison d'etre..." (Heur et malheur du guerrier, p. 125).

${ }^{41}$ Acerca de la descarga energética que habilita el combate en el guerrero lugoniano, MARTínez Estrada escribe: "Lugones necesitaba encontrarse limitado (o combatido) para ser fuerte. De ahí su necesidad de polémica (de golpear en sus límites); de ahí su estética, su política y su crítica. Pero también desbordaba esa limitación, no por necesidad espiritual sino por necesidad fisiológica... La necesidad de usar la fuerza sobrante..." (Leopoldo Lugones, retrato sin retocar, p. 134). 
definido como el "caso Lugones". Actividad lujuriosa y dispendiosa, la guerra lugoniana, como la fiesta, tiempo de lo sagrado en las sociedades primitivas, es ocasión para la dilapidación suntuaria de bienes y energías ${ }^{42}$. El combate construye en los textos lugonianos lo que con Bataille podemos definir como una suerte de potlach: una escena ritual que trascendiendo todo cálculo apunta a un gasto desconsiderado de recursos vitales ${ }^{43}$. Es la descarga agonística que habilita el combate en Lugones, y en la felicidad de un exceso que apunta al derroche y al gasto lujoso, donde cobra densidad la figura del héroe lugoniano. "La moral de la energía", esa "enérgica voluntad de vivir" (Estudios helénicos, pp. 144-145) se afirma en la muerte, en la pasión negativa y destructiva que muestra su escritura. Lugones lo dice claramente: "sin duda es necesario destruir y aún destruirse" (Primeras letras, p. 44).

Freud habla del instinto de muerte, de aquello que se inscribe "más allá del principio de placer" como compulsión traumática a la repetición ${ }^{44}$; Lacan, por su parte, localiza allí el espacio del goce, de aquello que, subvirtiendo la polaridad significante placer-displacer, escapa al orden simbólico ${ }^{45}$. Decir que la guerra lugoniana delimita su campo de batalla en ese espacio es ser fiel a la intensidad de su registro. Más allá de la forma y del sentido, más allá de la propia vida, de ese "principio de placer" que regula según Freud la continuidad vital de organismo, el héroe afirma en el furor del combate una tendencia a la disolución y a la muerte.

42 Sobre la guerra como fiesta véase Roger CAillois, Bellome ou la pente de la guerre, La Renaissance du Libre, Bruxelles, 1963.

${ }^{43}$ A propósito de la institución del potlach, George Bataille apunta: "Mais on a mal saisi le sens de la guerre et de la gloire s'il n'est rapporté, pour une part, á l'acquisition du rang par une depense inconsidérée des ressources vitales, dont le potlach est la forme la plus lisible" (La part maudite, Éds. du Minuit, Paris, 1967, p. 109).

44 "Más allá del principio de placer", Obras completas, t. 3, pp. 2507-2541.

45 Término de raigambre hegeliana (genuss), Lacan define al goce (jouisance) como una particularidad absoluta opuesta al deseo, entendido como deseo de reconocimiento, ajeno a la relativización que impone el orden universal del significante y de la ley. En su relectura de Freud, LACAN ubica el goce -que es siempre goce del cuerpo en tanto primera propiedad de cada sujeto- "más allá del principio de placer", en el orden de lo doloroso, inútil e improductivo (El seminario... Libro 20: Aun, trads. D. Rabinovich, Delmont-Mauri y J. Sucre, Paidós, Buenos Aires, 1992). Sobre el concepto de goce en Lacan, véase Néstor Braunstein, Goce, Siglo XXI, México, 1995. 
Las luchas de ayer no producen desfallecimientos en los espíritus elevados; son como la morfina y el coito, el insomnio o el alcohol: cuanto más se los usa mayor es el deseo y la necesidad de repetición. Cada día transcurrido, cada combate librado, cada escaramuza trabada, son nuevos estímulos para la continuación de la pelea ${ }^{46}$.

Trascendiendo el fantasma de un orden que podría proponer una fantasía burocrático-totalitaria “a lo Kafka”, lo que define la empresa heroica lugoniana como una experiencia fascista es un binomio antagónico: "la pasión por el orden", la movilización de este exceso al servicio de la disciplina, la inscripción en el registro compulsivo de la ley de esta energía pasional heterogénea al sentido y en sus extremos al contrato social.

Sade es una referencia obligada para toda lectura lugoniana. La lucha es en Lugones una actividad esencialmente afectiva. En el combate cuerpo a cuerpo que es la guerra lugoniana, la adicción de la batalla a la que alude Ingenieros, da cuenta de un goce que se afirma en su escritura en la experiencia voluptuosa y sádica del cuerpo del enemigo. La brutalidad del combate, el contacto violentamente afectivo con el otro, la intimidad de los cuerpos en el campo de batalla, se escribe en Lugones, como en Sade, en un registro que comparte la tortura con la experiencia erótica. La cita es obligada, sólo la experiencia alucinante del texto lugoniano puede dar cuenta de los afectos que moviliza en el héroe el contacto con su monstruo:

No se mueven las orejas del hipopótamo con sartas de cascabeles, ni se molesta su panza con las titilantes agujas de la frase amena. Para combatirlo, para dominarlo, se calza en el puño la manopla y se le rompe las costillas, se le descoyunta las vértebras, se le desnuca y también se le apedrea, se le escupe y se le epigramatiza. Sentarse sobre el predominante cogote de uno de esos bastos ricachos de cepa cananea, y enterrarle ligeros espolines en los flancos, es practicar sencillamente el oficio de Kornac. Pretender que los vicios sociales se curan por el influjo de álcalis galantes, es querer atar con riendas de seda los colmillos del jabalí. Decididamente hay que combatir a encinanzos (Primeras letras, p. 46).

${ }^{46}$ José Ingenieros, “Retrospección”, La Montaña, 1 de mayo de 1897, p. 6. 
LA CUEVA

Lectura inmanente la nuestra. Leemos a Lugones desde el propio Lugones. Tomamos en serio su palabra por momentos delirante. Creemos $a$ Lugones. Escépticos, sin embargo, lo que no hacemos es creer en Lugones. No creemos en el todo y en el absoluto que postula como objetivo la empresa heroica lugoniana. Si como sostiene Lévi-Strauss ${ }^{47}$, el mito no es sino una construcción imaginaria destinada a resolver una contradicción, por el revés del enfático y desmesurado yo guerrero lugoniano y su mítico ideal proyecto heroico de identidad, nos preguntamos: ¿cuáles son los límites y contradicciones de la empresa épica lugoniana? ¿Cuáles son las opacidades que escapan al circuito especular que construye la batalla? En Lugones ese espacio es una cueva.

Espacio de radical imposibilidad, la cueva constituye el límite último del proyecto de absoluto que es la épica en Lugones, el vacío sobre el que se asienta su utopía de un mundo y una identidad heroicas. Impasse en la formalización, la cueva es un hueco que, como tal, como vacío, puede leerse sobre el fondo del imaginario totalizante que construye la escritura lugoniana: "Un agujero visitado por todas las oscuridades del infierno", "el hueco de la sombra" (Primeras letras, p. 102), "el hueco del crepúsculo" (Las montañas del oro, p. 65), "una caverna... habitáculo de brujas", un "vertiginoso agujero" (La guerra gaucha, pp. 132, 233), el caos original, el Hades en Prometeo, los agujeros negros en El tamaño del espacio, los orificios del cuerpo, los huecos donde se materializa el deseo, "el genésico horror de las matrices" (Las montañas del oro, p. 49), los huecos del espacio social, el puerto-boca del país por el que penetran los inmigrantes, el zaguán de la patria en El payador, o ese "hueco sórdido" en el que vive la "montonera del suburbio" (Historia de Sarmiento, p. 245). La cueva es el punto cero del universo lugoniano, un espacio que, en su radical negatividad, escapa a la lógica polar, positivo-negativo, héroe-monstruo, vida-muerte, que regula el combate. De allí salió todo y allí termina todo: "El ser absoluto", escribe Lugones, "la absoluta energía en que todo se resume al concluir el universo su ciclo de manifestación material será los dos elementos a la vez, en un absoluto equilibrio equivalente a cero (+-)" (Las fuerzas ex-

47 Anthropologie structurale, Plon, Paris, 1958. 
trañas, p. 250). Entre otras tantas posibilidades, ese cero es, en Lugones, la luna: "cero en el minuendo", o "inexpresable cero en el infinito" en Lunario sentimental (pp. 53, 116). Sin embargo, y más allá de los múltiples lugares, o mejor aún, no-lugares que ocupe la cueva, es importante apuntar que se trata siempre de un espacio que trasciende la representación, "inexpresable", o como dice Lugones, "pura negación, o mejor dicho... la nulidad del vacío" (El tamaño del espacio, p. 18), "un estado inconcebible... Hay pues una imposibilidad absoluta de especular a su respecto" (Las fuerzas extrañas, p. 208).

La antropología (Bataille, Girard, Callois) hablaría del lugar de lo sagrado, del espacio que prohibido y excluido en el rito del sacrifico funda como imposibilidad lo humano y lo social. Kant apuntaría en la cueva el lugar de lo sublime, el espacio de aquello que escapa a la representación, de aquello cuya experiencia implica necesariamente el displacer. El psicoanálisis (Lacan) nos hablaría de lo real. Nosotros con Lugones hablamos de la cueva. Cero, nada, vacío, pura negación, la cueva designa un punto de imposibilidad en el ideal épico que sostiene el escritor (la cueva es lo que le falta al proyecto utópico lugoniano para concretarse), en el héroe guerrero (la cueva es lo que le falta al yo para ser un yo) y en lo simbólico de la épica (la cueva es un vacío que, como tal, el héroe no puede aceptar sin renunciar a su proyecto de absoluto).

En su búsqueda del mítico absoluto que guía como lema, programa y bandera su constante batallar, la misión del guerrero lugoniano no puede ser otra que cerrar la cueva, que cancelar esa imposibilidad, que representar ese límite a la representación y al conocimiento. La misión encomendada al Narciso heroico, construir un mundo absoluto, es en Lugones una tarea que se conoce como imposible. "Pobres tiempos éstos en que son absurdos los paladines", escribe el joven poeta hacia 1897, "si yo estuviera seguro que el Quijote suprimió la caballería odiaría a Cervantes" (Primeras letras, p. 47). Conociendo esta imposibilidad, el guerrero lugoniano es, sin embargo, incapaz de reconocerla, de integrarla simbólicamente, porque hacerlo supone reconocer su imposibilidad: lo absurdo e irrealizable del proyecto heroico que lo anima en su batalla. Más allá del conocimiento y la razón, el heroísmo se afirma en Lugones como una creencia que adquiere en su escritura caracteres de fe. Conforme la clásica fórmula de la $d \ell^{-}$ 
negación (Verneinung) estudiada por Manonni48, el héroe lugoniano parece decir: "Yo sé muy bien pero al mismo tiempo... Yo creo". Pero, ¿cómo conocer sin reconocer? ¿Cómo "saber" y al mismo tiempo "creer"? ¿Cómo conjugar ambos enunciados? No en vano Adorno ${ }^{49}$, en sus reflexiones sobre la épica, sostiene que hay un límite que empuja toda empresa heroica hacia la estupidez, la ingenuidad, la sin razón o la locura. Creer posible lo imposible y, al mismo tiempo, conocer su imposibilidad, exige necesariamente romper con la lógica proposicional que regula en el lenguaje el orden de la razón. ¿Cómo escribir entonces esta contradicción?

El combate sin cuartel que libra el poeta y guerrero lugoniano no tiene otro objeto que resolver esta contradicción, clausurar en su guerra permanente la distancia que la delata: la cueva, el vacío que media entre la realidad y la utopía. En el cruce que funda esta contradicción, "el heroísmo", dice Lugones, "proviene de la diferencia entre los medios materiales del héroe [la realidad] y su calidad espiritual expresa en la voluntad [utópica] de triunfar con ellos" (El payador, pp. 18-19). Inscrita en esta contradicción, en la cueva, pero negándola, la tarea heroica se revela en Lugones como una obsesión, como una fe que se afirma más allá de toda realidad, de toda razón, de toda dialéctica. "Nada en el cielo ni en la tierra: númenes adversos, elementos hostiles, hombres, fieras, pasiones", escribe Lugones, "pueden con la voluntad heroica o sea con la decisión del hombre de triunfar sin tener en cuenta la importancia de sus medios" (Estudios helénicos, p. 231). Poseído por una "megalomanía sublime" (Piedras liminares, p. 231), el héroe lugoniano se afirma, negando la imposibilidad de su empresa, a través de un exceso, de una desmesura, de una "desproporción heroica" (El payador, p. 18) que hace factible algo que en principio no lo parece: lo heroico. Así, dice el poeta: "el heroísmo caracterizado por la estupenda constancia. Zócalo de granito con que, en su propia cordura, daba apoyo la empresa al arrebato quimérico que no era

48 "Je sais bien, mais quand même...", Clefs pour l'imaginaire ou l'autre scène, Éds. du Seuil, Paris, 1969, pp. 9-33.

${ }^{49}$ La "ingenuidad" o "estupidez", características, según Adorno, del discurso épico, son para este crítico, resultado de la desintegración del orden proposicional del lenguaje que impone al género su rechazo de la "realidad primordial" que constituye su contexto de enunciación ("On epic naiveté", en Notes on literature, tr. S. Weber Micholsen, Columbia University Press, New York, 1991, t. 1, pp. 24-29). 
sino la negación de lo imposible" (Roca, p. 57). La voluntad del guerrero no basta, sin embargo, para fundar un mundo épico, pleno de significado, en el que la inmanencia del sentido cierre cualquier posibilidad a la indeterminación. Cuando más allá de la fe, del empeño obsesivo que anima al héroe lugoniano en su combate, se hace evidente en su escritura el fracaso de su proyecto épico de identidad, lo que aparece en sus textos es la cueva y, protuberante, dándole dimensión en su escritura, el monstruo lugoniano.

\section{El objeto de la BAtalla}

Lacan ha escrito: "Dire toute [la vérité], c'est impossible, matériellement: les mots y manquent. C'est même par cet impossible que la vérité tient au réel"50. Coherente con esta propuesta, nuestra lectura hace de esa negatividad radical que designa la cueva no sólo un límite al proyecto de absoluto que anima al guerrero, sino también la condición de su empresa heroica de identidad. Límite a ese "decirlo todo" que pretende y postula el proyecto heroico lugoniano, la cueva funciona en la escena especular que construye la batalla como lo que con Lacan podemos conceptualizar como el objeto a del universo épico lugoniano: una opacidad en el ideal heroico lugoniano, un vacío irreductible a la representación y al conocimiento, que otorga consistencia imaginaria a la empresa épica del poeta-guerrero afirmándola como lo que es, una utopía ${ }^{51}$. Ahora bien, ¿cómo escribir esta imposibilidad? ¿Cómo integrar simbólicamente algo que como la cueva lugoniana o el objeto a lacaniano escapa por definición a la representación y al conocimiento?

Lugones define la cueva como "una mención del absoluto incomunicable y también indefinible, a no ser por medio de negaciones" (Prometeo, p. 106). En "La negación", Freud sostiene que aquello que es imposible debe ser también prohibido. "La

50 Télévision, Éds. du Seuil, Paris, 1974, p. 9.

${ }^{51}$ El objeto $a$-objeto de la pulsión y objeto causa de deseo-constituye para Lacan, como falta, por un lado, un límite a la homeostasis del aparato psíquico dominado por el principio de placer, y por el otro, y al mismo tiempo, la condición de posibilidad de la constitución subjetiva de la realidad "objetiva”. Véase, JaCQues LACAN, El seminario. Libro 11: Los cuatro conceptos fundamentales del psicoanálisis, trad. D. Rabinovich, Paidós, Buenos Aires, 1993, pp. 181-193. 
negación", escribe Freud, "es una forma de percatación [de toma de conciencia] de lo reprimido" 52 . Objeto a del universo lugoniano, la cueva, ese hueco que como falta se lee en toda la escritura lugoniana, constituye esa imposibilidad de representación a la que alude Freud, y al mismo tiempo, de nombrarla.

El héroe lugoniano es, sin embargo, incapaz de aceptar la cueva como imposible. Hacerlo supone aceptar su propia imposibilidad, la imposibilidad de su yo y su proyecto de absoluto, aceptar un límite: el peso de la ley social y simbólica. Incapaz de aceptar esa imposibilidad, el héroe lugoniano es una figura incapaz de construir lo que Lacan ha llamado la Metáfora del Nombre del Padre, constitutiva de la subjetividad, aquella por medio de la cual el sujeto se integra en el orden social y simbólico, no ya como único y exclusivo, sino como un miembro más de la comunidad ${ }^{53}$. Incapaz de acceder al Nombre del Padre, es decir, de aceptar un límite a su empresa de absoluto, el objetivo del Narciso heroico en la batalla, de ese "Genio omnipotente que no conoce límite a sus ansias" (Primeras letras, p. 14), no puede ser otro que cerrar la cueva.

Habitante de la cueva como todos los monstruos, suerte de fetiche que oculta la castración, que obtura un vacío, el monstruo lugoniano (los inmigrantes, la mujer deseante, o esas manchas o defectos que persiguen al poeta) será la figura que, en su discurso bélico, dé consistencia positiva a la imposibilidad de la empresa heroica lugoniana, que cierre ese vacío de la representación y al conocimiento que el héroe no puede asumir como tal: la cueva. Conforme la lógica del repudio (Verwerfung/“forclusión") desarrollada por Lacan: "Lo que no ha llegado a la luz de lo simbólico aparece en lo real"54. Retorno desde lo real (desde aquello que Lacan cataloga como imposible, como irrepresentable), desde más allá de lo simbólico, desde la cueva, el monstruo funciona como lo que Lacan en su

52 “La negación”, en Obras completas, t. 3, pp. 2884-2886.

${ }^{53}$ Lacan define la Metáfora del Nombre del Padre como aquella que en la escena edípica permite al sujeto resolver el complejo de castración renunciando a su condición de único objeto del deseo materno - a su condición de falo de la madre, que diría Lacan- para acceder al orden del lenguaje en su identificación con la ley social. Véase, JacQues Lacan, "De una cuestión preliminar a todo tratamiento posible de psicosis", en Escritos 2, pp. 513-564.

54 "Respuesta al comentario de Jean Hypolite sobre la Verneinung de Freud", Escritos 1, p. 513. 
lectura de lo siniestro en Freud ha llamado un "doble real" 55 del héroe lugoniano, un objeto que da cuerpo imaginariamente en la escritura lugoniana a esa falta o pérdida que el sujeto se ha negado a asumir como lo que es.

La guerra constituye lo que llamamos el "modo de producción épico" lugoniano, porque por medio del combate y su dialéctica, y en la figura del monstruo, el yo heroico logra obturar la cueva, representar lo irrepresentable, hacer posible su imposibilidad, dar cuerpo a eso que, en su imaginario, escapa a la representación y al conocimiento: la cueva, o el objeto a para usar los términos de Lacan. "Yo sabía... pero creía", nos decía el héroe lugoniano. El monstruo es el retorno de ese saber que, omnipotente, el héroe lugoniano se había negado a reconocer, su imposibilidad, encarnada por el monstruo, figura que conjuga en el discurso lugoniano los dos términos de la contradicción que definían toda empresa épica para Lugones: el monstruo es la condición de (im) posibilidad de su proyecto heroico de identidad.

El surgimiento de lo siniestro en la escritura lugoniana, el paso de lo heim a lo unheim, del espacio familiar que encarna el ideal a la monstruosa diferencia, se produce cuando la cueva aparece visible, el objeto $a$ del universo lugoniano, su monstruo, doble real del héroe lugoniano, da cuerpo en su escritura al deseo que, en su afirmación soberana, el poeta-guerrero se negó a reconocer: el deseo del otro. Si en su voluntad de absoluto el yo épico no afirmaba sino un deseo no mediado que negaba cualquier deseo que no fuera el propio, el monstruo devuelve al héroe lugoniano a su condición, no de sujeto, sino de objeto de deseo del otro. No se trata del deseo de un semejante, sino del otro, el orden simbólico; aquel que define y otorga al sujeto una identidad en el orden social del lenguaje no ya como Narciso heroico, sino como un hombre más sometido a las limitaciones de la ley. Trascendiendo las limitaciones de esa ley que el héroe nunca reconoció, y la distancia que impone en el lenguaje el "como si" de la metáfora, el cuerpo del héroe lugoniano queda consumido por el deseo y el goce de ese monstruo que lo quiere manchar, devorar, "poseer".

55 Sobre la figura del "doble real" desarrollada por Lacan en su inédito Le seminaire. Livre 10: L'angoisse, remitimos a MLADEN DOLAR, "I shall be with you on your wedding-night: Lacan and the uncanny", October, 1991, núm. 58, 5-23; y a Diana Rabinovich, La angustia y el deseo del otro, Manantial, Buenos Aires, 1993. 
El horror que desata la figura del monstruo en la escritura lugoniana no es el clásico horror vacui, sino el horror plenitudinis. $\mathrm{Si}$, como sostiene Lacan, "L'angoisse c'est le défaut de cet appui du manque" 56 , la ansiedad que desata la figura del monstruo deja leer en su escritura el horror de un mundo sin límites, absoluto, un mundo épico en el que no habría lugar para el sujeto, el conocimiento, la reflexión o la representación de la realidad "objetiva", al cancelarse precisamente ese límite que los hace posibles como vacío, ausencia o cueva.

El monstruo materializa en la escritura lugoniana "algo más que el sujeto mismo", aquello a lo que el héroe lugoniano tendría que haber renunciado para poder vivir como un miembro "normal" de la comunidad: lo imposible, la cueva. Si el horror apunta la dimensión negativa de esa experiencia, el exceso gozoso en la batalla nos habla de un surplus, del retorno de una sustancia anterior a la mortificación simbólica que impone la constitución de la subjetividad y del orden comunitario: el goce. La erupción del monstruo "da cuerpo" en la escritura lugoniana a un plus de gozar, "algo más que la vida misma", algo que, más allá del deseo y del placer apunta al ámbito del instinto de muerte.

\section{IDEOLOGÍA Y METAMORFOSIS DEL HÉROE}

La crítica ideológica resulta insuficiente a la hora de dar cuenta del funcionamiento de la empresa heroica lugoniana. Lugones no fue un hombre de ideas sino, como sostiene Borges ${ }^{57}$, un hombre de "estilo". Y ese estilo, decimos nosotros, fue la violencia. "Las ideas y aún los ideales", como escribe Lugones a propósito de Sarmiento, "no fueron para él sino armas o instrumentos de su acción" (Historia de Sarmiento, p. 33). Toda aproximación ideológica al universo lugoniano está condenada a repetir lo obvio. No basta con señalar, como hace David

56 Le Seminaire. Livre 10: L’angoisse, lección 5-12-62.

57 "Las opiniones de Lugones - escribe Borges- fueron siempre menos encantadoras que la convicción y la retórica espléndida que les dedicó... Claudel o Chesterton o Shaw enriquecieron de problemas y argumentos las diversas doctrinas que han profesado, Lugones no aportaba a las empresas otra cosa que su adhesión acompañada de algunas metáforas" ("Lugones", Nosotros, 1938, núms. 26/28, 151-152). 
Viñas $^{58}$-junto con Borges uno de los mejores lectores de Lugones- que los sueños de grandeza lugonianos eran imposibles. No basta con decir que el fracaso del proyecto heroico lugoniano fue resultado de la incapacidad del escritor de reconocer e integrar una audiencia, un público que "reflejara" su pretendida imagen mayestática. $\mathrm{O}$ apuntar que su suicidio fue resultado de su soledad, de su misantropía, de su desdén por la alteridad. El yo heroico lugoniano no sólo estuvo solo, sino que también careció de cualquier necesidad de compañía, de un público que aplaudiera o "reflejara" sus gestos grandilocuentes. Tenía a su "compañero de armas", a su monstruo, aquel que, obturando la cueva, el vacío último de su proyecto, hacía posible la imposibilidad de su empresa. No cabe la menor duda de que el proyecto lugoniano no fue sino eso, un sueño, un delirio imposible. La mítica Argentina de El payador no sólo era imposible hacia el Centenario, sino que nunca existió, sus héroes no pasaron de ser una ficción literaria. Lugones, pese a los duelos y a la esgrima, estaba lejos de ser un paladín; sus faraónicos proyectos arquitectónicos carecían de cualquier posibilidad de concreción, sus pretensiones de pureza un absurdo. Pero aquello que hizo, y aún hoy hace imposibles semejantes proyectos, no fue el monstruo, esa diferencia paranoica que persigue al yo heroico y destroza su ideal épico de identidad (la mujer deseante, los inmigrantes, o esas manchas o defectos que acosan al poeta), sino una imposibilidad radical inherente a la naturaleza de todo proyecto de absoluto. Más allá de lecturas ideológicas o descripciones de imaginario de escritor ensayadas recientemente por la crítica lugoniana ${ }^{59}$, leer a Lugones exige ir más allá de la escena que construye su ideal heroico de identidad, buscar su enemigo, su monstruo y más allá del monstruo, el vacío último sobre el que descansa su proyecto épico-mítico de identidad: la cueva.

Ahora bien, toda reflexión sobre Lugones no puede ignorar, sin embargo, el problema que han planteado históricamente a la crítica las múltiples, constantes y desconcertantes trans-

58 "Suicidio del escritor burgués: Lugones", Literatura argentina y realidad política. De Sarmiento a Cortázar, Siglo Veinte, Buenos Aires, 1974, pp. 70-78.

59 Véase María Teresa Gramuglio, "Literatura y nacionalismo: Leopoldo Lugones y la construcción de imágenes de escritor”, Hispamérica, 1993, núms. 64/65, 5-22; y Jorge Monteleone, "Lugones: canto natal del héroe", Yrigoyen, entre Borges y Arlt (1916-1930), Contrapunto, Buenos Aires, 1989, pp. 161-180. 
formaciones del escritor. En efecto, como sostiene Borges, "Nadie habla de Lugones sin hablar de los cambios múltiples de Lugones"60. Cambios permanentes y espectaculares de estilo en la escritura, cambios compulsivos de domicilio, pero sobre todo, cambios ideológicos: socialismo, liberalismo y fascismo. "Maestro en el arte de las mudanzas", como se definió a sí mismo, la vida fue para Lugones una constante metamorfosis ${ }^{61}$. "Vivir", dice Lugones, "es renovarse continuamente y renovarse es cambiar" (El elogio de Ameghino, p. 76). Trascendiendo cualquier ortodoxia, sin embargo, la obra de Lugones es de entrada y sobre todo los múltiples Lugones que desconciertan a la crítica. La multiplicidad lugoniana es, en nuestra lectura, resultado de un modo de ser (heroico) que es en el escritor un modo de hacer (la guerra). Las metamorfosis lugonianas obedecen en nuestro análisis a los imperativos del combate, aparecen como su efecto natural. Es la "fricción" del combate, la inestabilidad que en el campo de batalla impone el acoso del enemigo, la que exige el movimiento, el cambio y con él la guerra. Escribe Lugones en La patria fuerte.

Por otra parte, en mecánica como en moral, todo equilibrio de fuerzas, es una resultante obtenida por compensación inestable entre elementos desiguales. Más esta disposición jerárquica de suyo, es también inestable, cuando se trata de elementos vivientes; y con ello en constante recomposición.

La estabilidad perpetua, llámese paz o lo que se quiera es un criterio de perfección metafísica. No existe, desde luego, en ningún campo accesible a nuestra experiencia, y no tenemos ningún motivo valedero para conjeturarla posible (p. 39).

60 "Lugones", p. 150.

61 A propósito de la permanente necesidad de cambio lugoniana, ALBerto Coníl-PAz, uno de sus mejores biógrafos, escribe: "Desde su arribo a Buenos Aires, los Lugones variaron de casa en más de treinta oportunidades, cubriendo un loco itinerario en el cual llegaron incluso a reincidir en anteriores domicilios... la más perpetua mutación... llega hasta el núcleo del hogar, troca el comedor en sala o la sala en comedor. A veces el traslado afecta sólo a ciertos sectores, o se limita al emplazamiento de algunos muebles, pero -implacable- es también capaz de hacerlo todo al mismo tiempo" (Leopoldo Lugones, Huemul, Buenos Aires, 1985, pp. 443-444). En la misma línea MARTíNEz EsTRADA apunta: "No permanecía, no podía permanecer quieto dos minutos. Correctamente sentado, se esperaba que como de un salto se pusiera a andar por la oficina en la que permanecía enclaustrado. Recorríala de arriba a abajo" (Lugones. Retrato sin retocar, p. 31). 
Figura excéntrica al orden social, en su absoluto rechazo de toda ley que lo trascienda, el Narciso heroico lugoniano repudia los efectos de lo que Lacan ha denominado el capitonage (Che voui?) o Althusser, la "interpelación simbólica", por medio de la cual el orden simbólico o la ideología atrapa y fija al sujeto constituyéndolo como tal y otorgándole un lugar en la red intersubjetiva de relaciones simbólicas que es el espacio social ${ }^{62}$. Vector libre, carente de sentido definido, en permanente movimiento, en su constante subversión de todo límite, el guerrero lugoniano puede decir y ser todo y todos a la vez: hoy socialista, mañana fascista, hoy poeta modernista, mañana físico teórico, hoy pedagogo, al día siguiente sacerdote teosófico. Las máscaras son muchas, detrás del discurso que las articula en la escritura lugoniana encontramos un hueco, un vacío de sentido, la cueva, la imposibilidad de asumir la imposibilidad de su proyecto de absoluto.

Más allá de sus múltiples metamorfosis, la cueva es el faro que debe guiar toda lectura del laberinto lugoniano. Su luz estridente en la escritura: el monstruo. ¿Cuáles son las estrategias que articula el yo heroico para obturar ese vacío? ¿Qué variables registra su relación bélica con el otro monstruoso? ¿Cómo las alternativas del combate se traducen formalmente en la economía de sentido que regula la escritura lugoniana y en las posiciones político-ideológicas del escritor? El mapa que dibuja la matriz estratégica de la guerra lugoniana reconoce tres etapas que, a su vez, conjugan tres elementos: $a$ ) el espacio (social y textual), $b$ ) el tiempo histórico y $c$ ) las ideologías.

1897-1903: Etapa de juventud del poeta soldado, el primer round de la guerra lugoniana se libra en los márgenes del espacio social y simbólico. Allí donde el poeta no ha logrado definirse y afirmarse como el poeta americano, como la figura heroica que pretendió ser, allí donde su yo no ha logrado aún imponerse como yo, allí donde el escritor no ha logrado convalidar imaginariamente su utopía mítico-heroica de identidad, la guerra lugoniana se libra desde un espacio que, más que social es asocial, un margen absoluto que confronta directamente la nada sobre

62 JaCQues Lacan, El seminario. Libro 3: Las psicosis, 3-319. Louis AlthusSER, "Ideology and ideological states apparatuses. Notes toward an investigation", Lenin and philosophy and other essays, pp. 121-173. Para una clara y reciente explicación de este proceso véase SLAVOJ Zızeck, The sublime object of ideology, Verso, London, 1989, pp. 102-104. 
la que descansa su empresa mítico-heroica de identidad: la cueva. El horror, el tono profético-apocalíptico de los textos de juventud del poeta - Las montañas del oro, Las fuerzas extrañas, o sus artículos publicados en el periódico La Montaña- deja leer en esta primera etapa de su guerra, la dimensión de esa nada y la angustia de un sujeto que lucha por su yo en los límites del simbolismo. La apuesta socialista revolucionaria y la lógica del sacrificio que la regula, configuran en el imaginario lugoniano una primera solución al conflicto insoluble que plantea su guerra: muerte del yo guerrero, pago de una deuda.

La segunda etapa de la guerra lugoniana se ubica entre los años 1903 y 1923. En el centro del espacio social, el "poeta nacional" parece encontrar una convalidación a sus sueños de absoluto. Lugones es consagrado "escritor nacional" e ingresa en el establishment político-literario argentino. El poeta ingresa en un doble sentido en las páginas del periódico La Nación. Su escritura parece poder materializar sus proyectos míticos. Lugones escribe épica: El payador, Prometeo, sus Estudios helénicos, La cacolita... El conflicto lugoniano encuentra otra solución: la síntesis, la armonía entre los contrarios. Al heroísmo del sacrificio se sucede la fórmula de la educación: educar al otro, construir una mediación que elimine la contradicción: didáctica. Un proyecto que se articula en lo político en su ideario liberal. A la revolución de sus años de juventud Lugones opone el mito de una sociedad armónica fundada en una lógica sintética. La solución armónica al conflicto se dará sobre tres espacios de identidad privilegiados por la escritura lugoniana: a) el arte, "consuelo de la belleza" según Lugones, $b$ ) la mujer y $c$ ) la lengua.

La tercera y última de estas etapas comprende los años 1923 a 1938. Un período marcado en lo ideológico por el giro del poeta hacia el fascismo. El conflicto europeo, la Gran Guerra, rompe en el imaginario lugoniano cualquier posibilidad de síntesis armónica, reactivando en su escritura la violencia en toda su brutalidad y esplendor. Al heroísmo de la síntesis sucede ahora la lógica de la venganza, del exterminio de la diferencia. A la educación como posibilidad de integración del otro sucede la propuesta lugoniana de construcción de campos de concentración para ese otro monstruoso, extraño y extranjero a su patria ideal: el inmigrante. El ejército, secta de elegidos, casta de hombres puros y hermosos, se postulará, en 
el Lugones fascista, como el último recurso frente al asedio de la diferencia.

Tres etapas y tres lógicas de guerra que, pese a recorrer múltiples registros de identidad -sociales, poéticos, políticos, estéticos, genéricos y lingüísticos- apuntan en su diversidad de soluciones un mismo proyecto y una misma voluntad: la construcción de un mundo total y absoluto, la definición de una plena identidad, la construcción de un mundo épico.

Juan Medrano Pizarro Dartmouth College 